\title{
The Effect of Rhizobium japonicum Inoculation on the Growth of Soybean Cultivars in Coastal Area
}

\author{
Okti Purwaningsih*, C. Tri Kusumastuti, Y. Sulistyo Nugroho and Casper Yoda Morib \\ Universitas PGRI Yogyakarta \\ Jln. IKIP PGRI I Sonosewu No.117, Ngestiharjo, Kasihan, Bantul, Yogyakarta 55182, Indonesia \\ *Corresponding author: okti_purwaningsih@yahoo.com
}

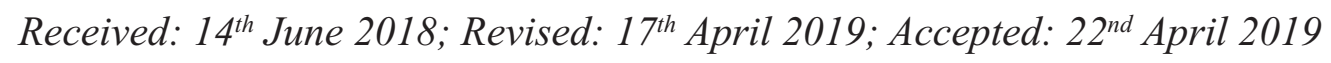

\begin{abstract}
The natural resources in the form of coastal area in Indonesia have the potential to be developed as agricultural land with the support of both cultivation technology and land processing which one of them can be done by using $R$. japonicum bacteria to meet the need of nitrogen in the soybean plants. This study aimed to determine the characteristics of nitrogen fixation in various soybean cultivars planted in the coastal area. The research was conducted in Mancingan, Parangtritis, Kretek, Bantul, Yogyakarta. The study was designed in Completely Randomized Design which consisted of two factors replicated three times. The first factor was $R$. japonicum inoculation (with inoculation and without inoculation) and the second factor was 10 cultivars of soybean (Grobogan, Burangrang, Argomulyo, Anjasmara, Dena 1, Gema, Kaba, Wilis, Sinabung and Gepak Kuning). The results showed that the inoculation of $R$. japonicum in soybean cultivars planted in coastal area could increase the number of root nodule, dry weight of root nodule, dry seed weight per plant and harvest index. Cultivar Burangrang planted in the coastal area was the most responsive to $R$. japonicum inoculation among other soybean cultivars tested.
\end{abstract}

Keywords: Nitrogen fixation, soybean cultivar, coastal area

\section{INTRODUCTION}

Soybean is a strategic food commodity as it serves both protein source for food and energy source for alternative fuel (Adie and Krisnawati, 2014). However, Indonesia still has to import soybeans to meet the domestic demand. During the period of $2010-2014$, the demand was \pm 2.3 million tons of dry beans year ${ }^{-1}$, while soybean production in 2015 was only 963.183 ton ha $^{-1}$ (BPS, 2016). Every year, Indonesia still has to import soybean \pm 1.3 million tons. The soybean production tends to decrease as the land area for cultivation is being transferred into the residential and industrial estate. Also, the farmers prefer to cultivate other food crops such as rice and corn. To reduce the dependence on the import, it is necessary to increase the soybean production by expanding the soybean cultivation area (extensification of agriculture). In 2015, the rice field area in Indonesia covered around 8 million ha, while the harvest area of soybean was only 614 thousand ha (BPS, 2016). Therefore, it is necessary to make efforts to expand the area for soybean cultivation by utilizing the marginal land that has not been widely used in Indonesia such as coastal area.

Indonesia as an archipelagic country has a long coastline of about $81,000 \mathrm{~km}$. Coastal areas have the potential of various natural resources that can be developed such as fisheries, livestock, agriculture, and tourism sector. The utilization of coastal areas for agricultural sector is experiencing some constraints which are salinity, low soil moisture and low content of nutrient and organic materials. Besides, during the day, the soil temperature can reach $55-60^{\circ} \mathrm{C}$ and the aeration runs faster. In addition, the structure and particles of the soil are loose so the soil porosity is very large. These conditions cause slower accumulation of organic matter and lower ability to hold water (Kertonegoro, 2006). Meanwhile, the sunlight and strong wind carrying water vapor with high salinity lead to the limited cultivars able to be planted in the coastal area. Hence, the soil and salinity conditions are the most important issues in planting the crops in the coastal areas. 
Soybean, as a strategic commodity in Indonesia, has high sensitivity to salinity and it becomes the main problem as it can affect the plant growth due to ionic and osmotic stress. One of the efforts to utilize the coastal area is done by improving the physical and chemical properties as well as soil organisms so that soil-water-plant interaction can be well occurred. Furthermore, the interaction between the plants and the atmosphere is necessary to be managed (Gunadi, 2002). According to Sudihardjo (2001), based on criteria of CSR / FAO (1983), the actual suitability of the Southern coastal area of Special Region of Yogyakarta (DIY) is classified into not suitable or marginally suitable for food crops and vegetables.

Improvement of the physical and chemical properties in a coastal area can be managed by the addition of organic materials (Gunadi, 2002). It can also be optimized by the application of Rhizobium japonicum bacteria. The cultivation of soybean in a coastal area requires a large amount of nutrients especially $\mathrm{N}$. The nitrogen requirement can be fulfilled if the fixation of $\mathrm{N} 2$ can be optimally conducted by the plants. The $\mathrm{N} 2$ fixation is determined by the suitability of the Rhizobium strain and the soybean cultivar. Therefore, it is necessary to conduct a study to find out the response of various soybean cultivars to Rhizobium inoculation suitable to be developed in a coastal area. The results of this study are expected to be used as the solution to optimize the utilization of marginal land in Parangkusumo coastal area of Bantul Regency for the development of soybean crops using low energy input by maximizing the symbiosis between soybean plants and Rhizobium bacteria to fix N2.

The fixation of $\mathrm{N} 2$ occurs because of the symbiosis between the plants and prokaryotic bacteria diazotroph, the bacterium that can inhibit the molecules of nitrogen gas in the air (MacDicken, 1994). The diazotroph organism produces a nitrogenase enzyme that acts as a catalyst in the decomposition of nitrogen gas and reduces into $\mathrm{NH}_{3}{ }^{+}$. The symbiosis between the Rhizobia and leguminous plant roots will produce nitrogen-blocking organs called as root nodules. In the root nodules, there are cells that are slightly enlarged containing bacteroid and among them, there are smaller cells containing starch. The shape, size, color, texture, and location of the root nodule on the plant will be determined by the host plant (Dierolf et al., 2001). The effectiveness of rhizobia is determined by the color of the root nodules, in which the pink root nodules are more effective in fixing the nitrogen than the white ones. This will affect the growth and yield of the host plants (Karaca and Uyanoz, 2012). Until 2016, the government has released 83 superior cultivars of soybean that have superiority in morphological and agronomic characteristic. The new improved cultivars released in 2014-2016 were Pearl 2 and Pearl 3 (black soybean); Demas 1 (Admix Soybean soybean); Dena 1 and Dena 2 (Shade tolerant soybean); Devon 1 (high isoflavone soybean); Dega 1; and Deja 1 and Deja 2 which are water-tolerant (Susanto and Nugrahaeni, 2017).

The results of Douka's research et al. (1986) and Aaron and Ammar (2001) showed that soybean cultivars would respond differently to Rhizobium inoculation. The study of Rhizobium inoculation on several varieties of Pisum sativum L. showed that the three varieties of Pisum sativum L. tested had a good result on root nodules; dry weight of root nodules; dry weight of root, and seed yield (Ali et al., 2008). Therefore, the aim of the experiment was to examine the characteristics of nitrogen fixation on various soybean cultivars planted in the coastal area.

\section{MATERIALS AND METHODS}

The research was conducted in Mancingan, Parangtritis, Kreek, Bantul DIY. The study was arranged in Complete Randomized Design (CRD) consisting of two factors with three replications. The first factor was $R$. japonicum inoculation (without inoculation and with inoculation of soybean legin) and the second factor was the various cultivars of soybean (Grobogan, Burangrang, Argomulyo, Anjasmara, Dena 1, Gema, Kaba, Wilis, Sinabung and Gepak Kuning). There were 20 treatment combinations tested in the research.

The planting media used was beach sand and cow manure (ratio of 1: 1) in polybag $(25 \mathrm{~cm} \times 30 \mathrm{~cm}$. The polybags used were installed with plastic plates to avoid the contamination. Before planting, the soybean seeds were inoculated with soybean legins were containing $R$. japonicum bacteria. Before the inoculation, soybean seeds were soaked in sugar solution so that soybean legin will be more easily attached to the seed. The inoculation treatment was done by mixing the seeds with soybean legin. The inoculation of soybean seeds was carried out in a shady place (not directly exposed to the sunlight).

The variables observed were the number of root nodules, dry weight of root nodules, and canopy $\mathrm{N}$ uptake that were performed at the maximum vegetative growth. The observations on the growth variables 
were performed at the time of vegetative growth $(8$ week after planting) including the leaf area and dry weight of the plant. The canopy $\mathrm{N}$ uptake was analyzed with Kjeldahl micro method. The observations on the yield variables were done at harvest time including the seeds weight per plant and harvest index.

The data were analyzed using analysis of variance at $5 \%$ significance level and followed with DMRT (Duncan's Multiple Range Test).

\section{RESULTS AND DISCUSSION}

The soil analysis was done to find out the nutrient content in the soil. The analysis was conducted on the sand soil samples in the research location and planting media in the form of beach sand and manure mixture. The soil analysis showed that the application of manure (ratio 1:1) was able to increase the nutrient content of organic $\mathrm{C}$, total $\mathrm{N}, \mathrm{P}_{2} \mathrm{O}_{5}$, and $\mathrm{K}_{2} \mathrm{O}$ (Table 1).

\section{Nitrogen Fixation Ability}

The ability of soybean cultivars in fixing N2 is determined by active root nodules. The more root nodules are active, the higher ability of soybeans in fixing N2 will be obtained. In this study, the ability of soybean in fixing N2 was observed from the number of root nodules; the dry weight of root nodules; and canopy $\mathrm{N}$ uptake. Table 2 shows the interaction effect between $R$. japonicum inoculation and various type of soybean cultivars on the formation of root nodules. This indicates that soybean cultivars provide a different response to the $R$. japonicum inoculation. Cultivar Anjasmara and Grobogan showed the best result on the number of root nodules and nodule dry weight. This result is supported by the study done by Purwaningsih (2012) on agricultural land in Banguntapan which showed that cultivar Anjasmara inoculated with $R$. japonicum had the significantly higher number of root nodules compared to cultivar Wilis, Sinabung, Gepak Yellow, Argomulyo, and Grobogan.

The study conducted by Purwaningsih (2012) classified cultivar Anjasmara, Argomulyo, Gepak Kuning into the groups of soybeans cultivar that resulted higher nitrogen fixation and seed yield as inoculated with $R$. japonicum. Meanwhile, cultivar Grobogan, Sinabung, Wilis are classified into the

Table 1. Nutrient content (N, P, K) and $\mathrm{pH}$

\begin{tabular}{llccc}
\hline No & Variables Observed & $\begin{array}{c}\text { The soil } \\
\text { of a coastal area }\end{array}$ & $\begin{array}{c}\text { The soilof coastal } \\
\text { area }+ \text { manure }\end{array}$ & Unit \\
\hline$(1)$ & $(2)$ & $(3)$ & $(4)$ & $(5)$ \\
\hline 1. & $\mathrm{pH}\left(\mathrm{H}_{2} \mathrm{O}\right)$ & 6.20 & 7.71 & \\
2. & $\mathrm{C}$-organic & 0.04 & 0.60 & $\%$ \\
3. & $\mathrm{N}$-total & 0.06 & 0.18 & $\%$ \\
4. & $\mathrm{P}_{2} \mathrm{O}_{5}$ potential & 152 & 209 & ${\mathrm{Mg} 100 \mathrm{~g}^{-1}}^{-1}$ \\
5. & $\mathrm{K}_{2} \mathrm{O}$ potential & 9 & 58 & ${\mathrm{Mg} 100 \mathrm{~g}^{-1}}$ \\
\hline
\end{tabular}

Table 2. The Average number and dry weight of root nodule on various soybean cultivar (Not inoculated and inoculated with $R$. japonicum)

\begin{tabular}{lcccc}
\hline \multirow{2}{*}{ Cultivar } & \multicolumn{2}{c}{ Number of root nodule } & \multicolumn{2}{c}{ The dry weight of root nodule (g) } \\
\cline { 2 - 5 } & Not inoculated & Inoculated & Not inoculated & Inoculated \\
\hline Grobogan & $0.00 \mathrm{~b}$ & $26.00 \mathrm{a}$ & $0.00 \mathrm{r}$ & $0.32 \mathrm{q}$ \\
Burangrang & $0.00 \mathrm{~b}$ & $12.80 \mathrm{~b}$ & $0.00 \mathrm{r}$ & $0.15 \mathrm{qr}$ \\
Argomulyo & $1.40 \mathrm{~b}$ & $1.60 \mathrm{~b}$ & $0.02 \mathrm{r}$ & $0.03 \mathrm{r}$ \\
Anjasmara & $0.40 \mathrm{~b}$ & $35.87 \mathrm{a}$ & $0.00 \mathrm{r}$ & $0.61 \mathrm{p}$ \\
Dena 1 & $0.40 \mathrm{~b}$ & $7.47 \mathrm{~b}$ & $0.00 \mathrm{r}$ & $0.07 \mathrm{r}$ \\
Gema & $0.47 \mathrm{~b}$ & $7.80 \mathrm{~b}$ & $0.01 \mathrm{r}$ & $0.18 \mathrm{qr}$ \\
Kaba & $0.00 \mathrm{~b}$ & $7.33 \mathrm{~b}$ & $0.00 \mathrm{r}$ & $0.13 \mathrm{qr}$ \\
Wilis & $0.00 \mathrm{~b}$ & $4.47 \mathrm{~b}$ & $0.00 \mathrm{r}$ & $0.09 \mathrm{r}$ \\
Sinabung & $0.00 \mathrm{~b}$ & $4.07 \mathrm{~b}$ & $0.00 \mathrm{r}$ & $0.04 \mathrm{r}$ \\
Gepak Kuning & $0.00 \mathrm{~b}$ & $5.93 \mathrm{~b}$ & $0.00 \mathrm{r}$ & $0.09 \mathrm{r}$ \\
\hline
\end{tabular}

Remarks: Values in each variable followed by the same letters are not significantly different based on the DMRT test at 5\% significance level. $(+)$ : there is interaction 
less-responsive group. This study indicates that in a different environment, soybean cultivar will respond differently to the inoculation of $R$. japonicum.

The ability of soybean plants in fixing nitrogen can be determined by the canopy $\mathrm{N}$ uptake. Table 3 shows that there is no interaction effect between $R$. japonicum inoculation and soybean cultivar on the canopy $\mathrm{N}$ uptake. This is due to the $\mathrm{N}$ content present in the canopy is not only derived from the $\mathrm{N} 2$ fixation but also comes from the $\mathrm{N}$ present in the planting medium. $R$. japonicum inoculation had no significant effect on the canopy $\mathrm{N}$ uptake as the low environmental stresses of soil moisture and high salinity caused ineffectiveness nitrogen fixation. This is supported by the result of correlation analysis which shows that canopy $\mathrm{N}$ uptake is not significantly correlated with the number of root nodules $(\mathrm{r}=0.25 \mathrm{~ns})$ and dry weight of root nodule $(r=0.23 \mathrm{~ns})$. This indicates that the $\mathrm{N}$-content in the canopy does not only originate from N2 fixation by root nodules.

Nitrogen requirements for the plants can be obtained through $\mathrm{N} 2$ fixation, both $\mathrm{NH}_{4}{ }^{+}$and $\mathrm{NO}_{3}{ }^{-}$absorption (Gerendas and Sattelmachner, 1990). Only nitrogen in the form of ammonium ions and nitrates is available for plants taken through rooting systems (Salisbury and Ross, 1991).

The soil moisture content in the planting medium used in this study was low and so was the ability of sand particles in binding the water 1 (even after the application of manure). The environmental conditions also tend to reach high evaporation as the water stress affects the nitrogen fixation (Yelton et al., 1983). In general, water stress affects the formation and function of root nodules, inhibiting the movement of bacteria to reach the root surface or encourage the attachment of soil particles on the root surface thus will inhibiting the attachment of Rhizobium and the host plants. Drought can cause nodule death as it can damage the plasmodesmata that connect to the root tissue and the host plant cells. The damage can continue in the form of the cell around the cells containing the bacterium in the nodule. The water strain results in decreasing activity of nitrogenase (Bordeleau and Prevost, 1994). The availability of water plays an important role in transporting the nitrogen fixation out of the root nodules. The results of nitrogen tethering that is not immediately transported out of the root nodules will accumulate in the root nodules thus inhibiting the efficiency of nitrogen fixation.

\section{Plant Growth Analysis}

The variables of leaf area and dry weight were observed when the plants reached the maximum vegetative stage at 8 weeks after planting. The results of analysis of variance showed interaction effect between rhizobium inoculation and various of cultivars on the leaf area and plant dry weight. (See Table 4).

The result showed that the inoculation of $R$. japonicum only gave significant effect on leaf area and dry weight of cultivar Burangrang. The inoculation of $R$. japonicum can increase the leaf area and dry weight of Burangrang cultivar. The inoculation of $R$. japonicum inoculation did not show any significant result on the leaf area and dry weight of cultivar Grobogan, Argomulyo, Anjasmara, Dena 1, Gema, Kaba, Wilis, Sinabung, Gepak Kuning cultivar. The inoculation of $R$. japonicum in these cultivars

Table 3. N uptake of the shoot (\%) of various soybean cultivar (uninoculated and inoculated with $R$. japonicum)

\begin{tabular}{lccc}
\hline Cultivar & Not inoculated & Inoculated & Average \\
\hline Grobogan & 1.64 & 1.90 & $1.77 \mathrm{abcd}$ \\
Burangrang & 1.97 & 2.46 & $2.22 \mathrm{ab}$ \\
Argomulyo & 1.93 & 1.93 & $1.93 \mathrm{abcd}$ \\
Anjasmara & 2.27 & 2.28 & $2.28 \mathrm{a}$ \\
Dena 1 & 1.58 & 1.88 & $1.73 \mathrm{bcd}$ \\
Gema & 1.73 & 2.29 & $2.01 \mathrm{abc}$ \\
Kaba & 1.76 & 1.51 & $1.63 \mathrm{~cd}$ \\
Wilis & 2.10 & 2.18 & $2.14 \mathrm{abc}$ \\
Sinabung & 2.25 & 1.75 & $2.00 \mathrm{abc}$ \\
Gepak Kuning & 1.32 & 1.66 & $1.49 \mathrm{~d}$ \\
\hline Average & $1.85 \mathrm{p}$ & $1.99 \mathrm{p}$ & $(-)$ \\
\hline Remarks: Values in the same column or row followed by the same letters are not significantly
\end{tabular}


Table 4. The Effect of $R$. japonicum inoculation on leaf area, dry weight of the plant

\begin{tabular}{lcccc}
\hline \multirow{2}{*}{ Cultivar } & \multicolumn{2}{c}{ Leaf Area $\left(\mathrm{cm}^{2}\right)$} & \multicolumn{2}{c}{ The dry weight of the plant $(\mathrm{g})$} \\
\cline { 2 - 5 } & Not inoculated & Inoculated & Not inoculated & Inoculated \\
\hline Grobogan & $11.66 \mathrm{~d}$ & $12.60 \mathrm{~cd}$ & $7.70 \mathrm{pq}$ & $12.28 \mathrm{p}$ \\
Burangrang & $3.70 \mathrm{e}$ & $15.22 \mathrm{abc}$ & $0.91 \mathrm{r}$ & $10.15 \mathrm{pq}$ \\
Argomulyo & $16.34 \mathrm{ab}$ & $17.78 \mathrm{a}$ & $8.60 \mathrm{pq}$ & $7.55 \mathrm{pq}$ \\
Anjasmara & $14.99 \mathrm{abc}$ & $15.53 \mathrm{abc}$ & $8.75 \mathrm{pq}$ & $8.95 \mathrm{pq}$ \\
Dena 1 & $14.18 \mathrm{bcd}$ & $15.82 \mathrm{abc}$ & $8.76 \mathrm{pq}$ & $8.14 \mathrm{pq}$ \\
Gema & $17.15 \mathrm{ab}$ & $15.89 \mathrm{ab}$ & $10.07 \mathrm{pq}$ & $7.42 \mathrm{pq}$ \\
Kaba & $17.56 \mathrm{a}$ & $15.95 \mathrm{ab}$ & $8.23 \mathrm{pq}$ & $6.53 \mathrm{pq}$ \\
Wilis & $14.91 \mathrm{abc}$ & $15.17 \mathrm{abc}$ & $7.08 \mathrm{pq}$ & $6.76 \mathrm{pq}$ \\
Sinabung & $15.16 \mathrm{abc}$ & $15.74 \mathrm{abc}$ & $8.39 \mathrm{pq}$ & $6.80 \mathrm{pq}$ \\
Gepak Kuning & $15.50 \mathrm{abc}$ & $15.95 \mathrm{ab}$ & $8.86 \mathrm{pq}$ & $5.39 \mathrm{qr}$ \\
\hline \multicolumn{5}{c}{} \\
\hline
\end{tabular}

Remarks: Values in each variable followed by the same letters are not significantly different based on the DMRT test at 5\% significance level. $(+)$ : there is interaction

Table 5. The The Average of dry seed weight per plant and harvest index

\begin{tabular}{lcccccc}
\hline \multirow{2}{*}{ Cultivar } & \multicolumn{3}{c}{ Dry seed weight per plant $(\mathrm{g})$} & \multicolumn{3}{c}{ Harvest index } \\
\cline { 2 - 7 } & Not inoculated & Inoculated & Average & Inoculated & Not inoculated & Average \\
\hline Grobogan & 0.99 & 1.05 & $1.02 \mathrm{ab}$ & 0.15 & 0.11 & $0.13 \mathrm{pgrs}$ \\
Burangrang & 0.00 & 0.66 & $0.33 \mathrm{c}$ & 0.00 & 0.08 & $0.04 \mathrm{~s}$ \\
Argomulyo & 0.52 & 1.00 & $0.76 \mathrm{ab}$ & 0.07 & 0.18 & $0.12 \mathrm{pqrs}$ \\
Anjasmara & 0.63 & 0.74 & $0.68 \mathrm{~b}$ & 0.08 & 0.09 & $0.09 \mathrm{rs}$ \\
Dena 1 & 0.55 & 1.02 & $0.79 \mathrm{ab}$ & 0.07 & 0.14 & $0.11 \mathrm{qrs}$ \\
Gema & 1.00 & 1.12 & $1.06 \mathrm{ab}$ & 0.15 & 0.21 & $0.18 \mathrm{pq}$ \\
Kaba & 0.84 & 1.20 & $1.02 \mathrm{ab}$ & 0.15 & 0.22 & $0.18 \mathrm{pq}$ \\
Wilis & 0.77 & 0.68 & $0.72 \mathrm{ab}$ & 0.13 & 0.13 & $0.13 \mathrm{pqrs}$ \\
Sinabung & 0.59 & 1.08 & $0.83 \mathrm{ab}$ & 0.12 & 0.15 & $0.14 \mathrm{pqr}$ \\
Gepak Kuning & 0.89 & 1.28 & $1.09 \mathrm{a}$ & 0.12 & 0.28 & $0.20 \mathrm{p}$ \\
\hline Average & $0.68 \mathrm{q}$ & $0.98 \mathrm{p}$ & & $0.11 \mathrm{y}$ & $0.16 \mathrm{x}$ & $(-)$ \\
\hline
\end{tabular}

Remarks: Values in the same column or row followed by the same letters are not significantly different based on the DMRT test at $5 \%$ significance level.

was not able to increase the leaf area and dry weight of plants.

Cultivar Burangrang has smaller leaf area as it accumulates lower dry matter (resulting from photosynthesis) than other cultivars. Therefore, the leaf area and dry weight will increase significantly after inoculated with the $R$. japonicum .

\section{Seed Yield}

The inoculation of $R$. japonicum in soybean was able to increase the harvest index and dry weight of seeds per plant. This is related to the ability of plants to supply nutrients for the plant growth, especially for the seed formation. Soybean requires $\mathrm{N}$ nutrients for growth, especially in the forming and filling period of seed. Lack of water and nutrients in this period will affect the yield. The harvest index describes the ability of plants to distribute the results of photosynthesis to economical yield for the seed formation. The inoculated plants had higher amount of photosynthesis results for seed formation than non-inoculated ones. The harvest index and dry seed weight can be seen in Table 5 .

The inoculation improved seed yield significantly. This indicated that the results of photosynthesis were mostly used for seed formation than for dry weight of the plant. The correlation analysis showed significant negative correlation between harvest index and plant 
dry weight $(\mathrm{r}=-0.33)$. On the contrary, harvest index correlated positively with seed weight per plant $(r=$ $\left.0.75^{* *}\right)$. Lower dry weight of the plants will increase the harvest index and the weight of the seeds per plant.

\section{CONCLUSIONS}

The inoculation of $R$. japonicum in some soybean cultivars planted in the coastal area effectively increased the number of root nodules and dry weight of the root nodule (the $\mathrm{N} 2$ fixing organ in nitrogen fixation). The ability to fix nitrogen was followed by the increase of crop yield. The inoculated cultivar showed higher harvest index and seed weight per plant than non-inoculated ones. Cultivar Burangrang was more responsive to $R$. japonicum inoculation in coastal area than Grobogan, Argomulyo, Anjasmara, Dena 1, Gema, Kaba, Wilis, Sinabung and Gepak Kuning.

\section{REFERENCES}

Adie, M.M. and A. Krisnawati. 2014. Soybean opportunity as source of new energy in Indonesia. Int. Journal of Renewable Energy Development., 3:37-43.

Ali, M.E., D. Khanam., M.A.H. Bhuiyan., M.R. Khatun and M.R. Talukder. 2008. Effect of rhizobium inoculation to different varieties of gardenpea (Pisum sativum L.). J. Soil. Nature., 2:30-33.

Badan Pusat Statistik - The Central Institution of Statistics. 2016. Produksi kedelai menurut provinsi-soybean production by province data (ton), 1993-2015. https://www.bps.go.id/ link TableDinamis/view/871.

Badan Pusat Statistik-The Central Institution of Statistics. 2016. Luas panen kedelai menurut provinsi-the harvest area of soybean by province data. https://www.bps.go.id/dynamic table/2015/09/09/870/luas-panen-kedelaimenurut-provinsi-ha-1993-2015.html.

Dierolf, T., T. Fairhurst and E. Mutert. 2001. Soil fertility kit. Potash \& Phosphate Institute of Canada.

Douka, C.E., A.E. Nychas and A.C. Xenoulis. 1986. Nitrogen fixation in soybeans as influenced by cultivar Rhizobium strain differences. Biology and Fertility of Soils., 2:113-118.

Farhoudi, R. and M.M. Tafti. 2011. Effect of salt stress on seedlings growth and ions homeostasis of soybean (Glysin Max) cultivars. Advances in Environmental Biology., 5: 2522-2526.
Gerendas, J. and Sattelmachner. 1990. Influence of nitrogen form and concentration on growth and ionic balance of tomato (Lycopersicon esculentum) and potato (Solanum tuberosum). Proceedings of the eleventh International Plant Nutrition Colloqium, 30 July - 4 August 1989. Wageningen, The Netherlands.

Gunadi, S. 2002. Teknologi pemanfaatan lahan marginal kawasan pesisir. Jurnal Teknologi Lingkungan - The Technology for Utilizing The Coastal Zone Marginal Land., 3:232236.

Harun, M.U. and M. Ammar. 2001. Respon kedelai (Glycine max L. Merr) terhadap Bradyrhizobium japonicum strain Hup+ pada tanah masam. The Response of soybeans (Glycine max L. Merr) to Bradyrhizobium japonicum Hup + strain on acid soils. Jurnal Ilmu-Ilmu Pertanian Indonesia., 2:111-116.

Karaca, U. and R. Uyanoz. 2012. The effectiveness of native Rhizobium on nodulation and growth properties of dry bean (Phaseolus vulgaris L.). African Journal of Biotechnology., 37:8986-8991.

Kertonegoro, B.D. 2006. Bahan humus tanah. Laboratorium Fisika Tanah Jurusan Ilmu Tanah Fakultas Pertanian - The Humus Material of Soil. Soil Physics Laboratory, Department of Soil Science, Faculty of Agriculture Universitas Gadjah Mada.

MacDicken, K.G. 1994. Selection and management of nitrogen-fixing trees. FAO/Winrock International Institute for Agricultural Development.

Purwaningsih, P., D. Indradewa, S. Kabirun, D. Shiddieq. 2012. The agronomic and physiological responses of soybean cultivar to the rhizobium japonicum inoculation and application of rice compost straw. Dissertation. Faculty of Agriculture, Universitas Gadjah Mada.

Sudihardjo, A.M. 2001. The shallot cultivation in the south coastal area of Yogyakarta sand shelf to support regional development. Proceedings of the Agricultural Technology Seminar to Support Agribusiness in Regional Economic Development and Food Security BPTP Yogyakarta.

Susanto, G. W. A. dan N. Nugrahaeni. 2017. Pengenalan karakteristik varietas unggul kedelai-The introduction of The characteristics of soybean superior varieties. http://balitkabi.litbang. pertanian.go.id/wp-content/uploads/2018/03/ bunga_rampai_2017_2_gatut.pdf

Yelton, M.M., S.S. Yang., S.A. Eddie., S.T. Lim. 1983. Characterization of an effective salt- tolerant, fast-growing strain of $R$. japonicum. Journal of General Microbiology., 129:1537-1547. 